для всіх», «школа для всіх», забезпечення яких спирається на повноваження муніципалітетів та діяльність Міністерства молодіжної політики.

Законодавче впровадження інклюзивної освіти в Німеччині розпочалося в кінці XIX ст. й набуло широких масштабів з 70-pp. XX ст. Німеччина належить до держав, у яких імплементація інклюзивної освіти здійснюється за принципом «зверху вниз», наявний чіткий розподіл функцій між державною та регіональною сферами управління освітою, держава бере на себе фінансування додаткових посад вчителів, витрат на дітей 3 особливими потребами (до $75 \%$ ), фінансування служб, що функціонують поза межами шкіл, запроваджує квоти на навчання неповносправних у закладах всіх рівнів і несе відповідальність за імплементацію інклюзії.

Перспективними в подальших наукових розвідках $є$ дослідження інклюзивної парадигми 3 проекцією на історичне становлення інклюзії в освітніх системах інших країн Європейського Союзу.

\title{
Література
}

1. Зарубежный опыт: интеграция инвалидов Германии в общественную жизнь [Электронный ресурс]. - Режим доступа: http://www.radugazvukov.ru/istok_audio_ trading/inclusive/news/?ELEMENT_ID=5730 2. Малофеев Н. Н. Западная Европа: эволюция отношения общества и государства к лицам с отклонениями в развитии / Н. Н. Малофеев - М. : «Экзамен», 2003. - 256 с. 3. Молодіжна політика у Німеччині [Електронний ресурс]. - Режим доступу : http://trendpolicy.ru/molodezhnaja-politika-vgermanii.html. 4. Смолонская А. Н. Основы организации инклюзивного образования в Германии [Електронний ресурс]/ А. Смолонская. - Режим доступу: http://mggush.ru/sites/default/files/smolonskaya.pdf 5. Convention on the rights of persons with disabilities (2006). [Електронний pecypc].- Режим доступу: (http://www.un.org/disabilities/documents/convention/convoptprot-e.pdf) 6. «Einfach machen». Unser Weg in eine inklusive Gesellschaft Nationaler Aktionsplan der Bundesregierung zur Umsetzung des Übereinkommens der Vereinten Nationen über die Rechte von Menschen mit Behinderungen (2011). [Електронний ресурс].- Режим доступу : http:/www.bmas.de/SharedDocs/Downloads/DE/2011_06_15_ nap.pdf?_blob= publicationFile. 7. Schulgesetz für das Land Nordrhein-Westfalen. Stand: 15. 4. 2011 (2011). [Електронний ресурс]. - Режим доступу : http://www.schulministerium.nrw.de/ BP/Schulrecht/Gesetze/ SchulG_I nfo/Schulgesetz.pdf. 8. Sozialgesetzbuch Achtes Buch Kinder- und Jugendhilfe [Електронний ресурс].- Режим доступу :http://bundesrecht. juris. de/sgb 8/. 9. Thalheim St. Inklusion im Kindergarten. Qualitätdurch Qualifikation, Reutlingen / St. Thalheim, J. Jerg., W. Schumann (Hrsg.) IQUA. Ev. Fachhochschule Reutlingen-Ludwigsburg, Diakonie Verlag, 2008 10. Verordnung über die sonderpädagogische Förderung, den Hausunterricht und die Schule für Kranke. Stand: 1. 7. 2010 (2010). [Електронний ресурс]. - Режим доступу: http://www.schulministerium. nrw.de/BP/ Schulrecht/APOen/AO_SF.pdf.

УДК 378. 147

Олена Драшко

\section{ОСОБЛИВОСТІ ПІДГОТОВКИ ВЧИТЕЛІВ ТЕХНОЛОГІЇ: РЕТРОСПЕКТИВНИЙ АНАЛІЗ}

Драшко О. М. Особливості підготовки вчителів технології: ретроспективний аналіз.

У статті сконцентровано досвід професійної підготовки вчителів технології в Україні та в Республіці Польща. Зосереджено увагу на розвитку системи підготовки 
майбутніх педагогів технології (трудової підготовки, обслуговуючої праці) окремих її компонентів.

Ключові слова: підготовка вчителів обслуговуючої праці, трудова підготовка, технічне виховання.

Драшко Е. Н. Особенности подготовки учителей технологии: ретроспективный анализ.

В статье сконцентрирован опыт трудовой подготовки учителей технологии в Украиненашого государства и в Республике Польша. Сосредоточено внимание на развитии системы подготовки будущих учителей технологи (трудовой подготовки, обслуживающего труда) и отдельных ее компонентов.

Ключевые слова: подготовка учителей обслуживающего труда, трудовая подготовка, техническое воспитание.

Drashko E.N. Features of preparation of teachers of technology: retrospective analysis.

The article deals with the experience of labour preparation teachers in Ukraine and in Republic of Poland. Attention is concentrated on the system of preparation of future teachers technologists (labour preparation, attendant labour) and its separate components.

Key words: preparation of teachers of attendant labour, labour preparation, technical education.

Становлення сучасної моделі системи педагогічної освіти, принципи організації підготовки педагогічних кадрів стали результатом орієнтації держави і суспільства на мету, пріоритети й основні напрями в підготовці вчителів. Кожна історична епоха вносила свої корективи в процес підготовки педагогічних кадрів.

Про професійну підготовку майбутнього вчителя в процесі освіти, як найважливішу функцію існування і розвитку людського суспільства вказували такі дослідники, як: Н. Андреєва, В. Жигірь, Л. Зарічна, О. Коберник, Н. Кортяхов, Н. Кравченко, Б. Прокоповича, В. Сидоренко, Д. Тхоржевський, В. Сластьонін та ін. Важливе місце в системі підготовки висококваліфікованих кадрів дослідники відводять професійній підготовці фахівців 3 вищою освітою. Від неї залежить виховання всього підростаючого покоління. Водночас мало дослідженою залишається проблема з вивчення особливостей підготовки майбутніх учителів технологій.

Mema cmammi: схарактеризувати особливості підготовки вчителів технології (обслуговуючої праці) в Україні та в Республіці Польща.

На педагогічну освіту, зокрема на іiі структурні модифікації досі впливають традиції «нормальних» шкіл, або так званої семінаристської педагогічної освіти. Головною метою підготовки $є$ оволодіння моделлю вчительського ремесла. На організаційному рівні ця традиція виявляється в існуванні різних моделей учительської підготовки як у межах окремих країн, так і в західноєвропейському масштабі.

Необхідність підготовки молоді до професії було зорієнтоване i трудове навчання в загальному шкільництві на польських землях наприкінці XIX-XX століть. Програма 3 трудового навчання була збагачена працею 3 природним, паперовим та текстильним матеріалом (у групі дівчат). 3 реалізацією програми трудового навчання була пов'язана підготовка польських учителів у цій галузі, організовані у 1915 році курси (державні річні курси ручних робіт). У зв'язку 3 недостатньою річною підготовкою вчителів, курси від 1923 року були перетворені в державний інститут 
ручних робіт (ДІРР). ДІРР давав формальні кваліфікації для навчання ручної праці у загальноосвітніх школах, але його випускники мали можливість скласти після двох років роботи у школі державний іспит 3 педагогічних предметів і отримати право навчати ручної праці в учительських семінаріях і середніх школах. План навчання в інституті охоплював 42 години занять на тиждень, а в тридцятих роках XX ст., у зв,язку із збагаченням програми фізикою та електротехнікою, був збільшений до 46 годин [9].

Історичні дані свідчать, що не розв'язали проблему підготовки й наявні різноманітні курси в Україні. Лише 20 травня 1930 р. колегія Наркомосу прийняла постанову «Про реорганізацію системи педагогічної освіти», згідно 3 якою мали відкриватися «індустрійні педтехнікуми» для підготовки інструкторів виробничого навчання та викладачів ручної праці.

У довіднику про правила вступу до технікумів і ВН3 України в 1932/33 навчальному році названі лише 4 інструкторсько-педагогічні технікуми Харківський, Київський, Дніпропетровський і Запорізький 3 терміном навчання 3 роки. Щодо профілю підготовки передбачалося, що випускник інструкторськопедагогічного технікуму - це «...інструктор шкільної майстерні (по дереву або металу) в установах - ФЗУ, ШКМ, дитячого будинку. У 1935 році з 72 педагогічних технікумів спеціалістів цієї кваліфікації готували лише 7 [9, с. 86]. Вивчаючи систему трудового виховання А. Вихрущ визначає: «Не розв'язали проблеми й педагогічні заклади 50-х років. Маємо на увазі додаткову спеціальність випускників фізикоматематичних i природничих факультетів. Лише 3 відкриттям загально-технічних факультетів удалося значно поліпшити рівень професійної підготовки вчителів трудового навчання» [1, с. 32].

Концептуальні ідеї інтеграції, професіоналізації, універсалізації тощо (педагогічні реформи 60-х та 80-х рр.), ставши головним напрямом у галузі освіти на європейському континенті, реалізуються в оптимальному структуруванні та інтеграції знань у змісті підготовки вчителя, у різних теоретично обгрунтованих моделях $\mathrm{i}$ підходах. Об'єднуючим центром професіоналізації викладання $є$ Свропейська асоціація педагогічної освіти. Вона організовує й проводить загальноєвропейську дискусію $з$ окресленої проблеми, вихідним положенням якої $є$ невідповідність вимогам професії.

Нині розв'язання проблеми професіоналізації підготовки вчителя пов'язане 3 науковим обгрунтуванням і практичним удосконаленням змісту педагогічної освіти в напрямі більшої збалансованості іiї складників: загального, спеціального й професійного (педагогічної теорії та практики). Першочергового розроблення потребує база професійних знань учителя, яка має включати не тільки знання концепцій, технологій i володіння педагогічною технікою, а й уміння розвивати й оцінювати свою професійну діяльність.

Структура дисциплін обслуговуючої праці як частина трудового навчання i виховання (трудове навчання - загальноосвітній предмет, який на сьогодні становить основу предметного наповнення освітньої галузі «Технологія»), пов'язана 3 практикою підготовки підростаючих поколінь, що історично склалася, до життя у процесі залучення їх дорослими в суспільні відносини і наочно-практичну діяльність відповідно до віку. Такі природовідповідні підходи до трудового навчання i виховання молоді, що зародилися в надрах первіснообщинного устрою і згодом розвинуті в умовах сім'ї і школи, обумовлені фізіологічними, психологічними аспектами, включаючи характер і зміст життя суспільства, його звичаї і традиції. Трудова підготовка дівчаток по обслуговуванню сім’ї і домівки (рукоділля, 
домогосподарство, догляд за дітьми) закріпилася в структурі шкільного жіночої освіти XVIII-XIX століть.

Починаючи з 50-х років XX століття і до теперішнього часу шкільний зміст трудової і професійної підготовки дівчаток, зорієнтованої на сферу послуг, має як виробничу, так і побутову спрямованість, особливо посилилася останніми роками. 3 одного боку, воно спирається на старі в педагогічних системах багатовікові традиції трудового навчання $\mathrm{i}$ виховання, з іншою, - визначається конкретними потребами сучасного суспільства. Його структура включала низку технологічних блоків (технологія оброблення тканини, волоконних і природних матеріалів, харчових продуктів, електротехнічні, ремонтні роботи), які близько сорока років вивчались в V-VII, а у ряді шкіл - V-XI класах, i по програмному об'єму навчального матеріалу і бюджету часу не поступались підготовці школярів з технічної і сільськогосподарської праці.

Політехнічна сутність, технологічна насиченість змісту навчання обслуговуючої праці у школі і багатогалузевої сфери послуг, зростаючі матеріальні і духовні потреби суспільства у впорядкуванні побуту ще 3 кінця 50-х років гостро актуалізували проблему підготовки вчителя обслуговуючої праці в педагогічному ВНЗ.

Проте, у 1957 році у практику вищої педагогічної школи була введена підготовка вчителя праці до навчання тільки технічної і сільськогосподарької праці. Учитель обслуговуючої праці за такими навчальними планами не готувався. Це привело до виникнення явних перекосів у забезпеченні загальноосвітніх установ педагогічними кадрами цієї спеціальності.

У 70-ті роки, з розвитком в Україні загальної середньої освіти ще більше загострилася проблема браку педагогів спеціальності. Вона з'явилася причиною повсюдного залучення до навчання школярів обслуговуючої праці вчителів різних спеціальностей або інженерів без педагогічної освіти, а також випускників педагогічних училищ.

На дуже проріджені ряди польських учителів звернуло увагу і Міністерство освіти Польщі, тому зарахувало ручну працю до вивчення обов'язкових предметів у базовій школі, у педагогічних ліцеях і спеціальних школах. Серед матеріалів, які були включені у програму, був і розділ з домашнього господарства для дівчат [8].

У Польщі для підготовки учителів - спеціалістів, починаючи 31959 року відкриваються університети, педагогічні інститути з напрямом «технічне виховання». Разом $з$ тим почала зростати критика підготовки вчителів , 3 огляду на кількість технічних предметів. Їх кількість перевищила 20 [10].

Різний підхід вищих навчальних закладів до професійної спеціалізації (різна кількість годин, до планів вводились різні предмети, які в одних вищих школах реалізувалися, а в інших ні, збільшувалась кількість годин на вивчення фізики, що значною мірою розширювало основи вивчення технічних предметів) став причиною уніфікації навчальних планів і програм.

У 1973 році Вільнюським педагогічним інститутом розпочинається підготовка вчителів хімії 3 додатковою спеціальністю «Обслуговуюча праця», а в 1983 Московським ім. Н. Крупскої і Черкаським педагогічними інститутами, що було спробою практичного розвязання означеної проблеми. Ї̈̈ актуальність, багатоплановість і неопрацьованість послужили об'єктивною підставою для дослідження в 1983-1990 роки на базі Черкаського педінституту, змісту, форм i методів підготовки вчителя обслуговуючої праці в педвиші, що базується на педагогічно орієнтованому поєднанні іiї спрямованості на матеріальне виробництво, сферу послуг і домашній побут [2].

Аналіз досліджень свідчить про те, що підготовка вчителів, як у нашій країниі, 
так і Польщі, здійснювалась із технічним спрямуванням.

Тому починають відкриватися професійні заклади, як визначає С. Мазуренко, «метою яких є навчання професії» [5, с. 45].

Лише у 1986 році у Криворізькому педагогічному університеті розпочато підготовку вчителів обслуговуючої праці [4, с. 82].

Професійна підготовка - процес формування спеціаліста для однієї із сфер трудової діяльності, пов'язаної з оволодінням певним родом занять, професій. Метою професійної підготовки визначають набуття професійної освіти в результаті засвоєння систематизованих знань, умінь, навичок та необхідних особистісно-професійних якостей.

Цю думку підтверджує Я. Цехмістер: «підготовка повинна включати ознайомлення студентів з науковими основами й технологією обраного виду праці, прищеплення практичних навичок і вмінь, формування психічних i моральних якостей особистості» [7, с. 61].

При цьому пріоритетним завданням вищої школи на сучасному етапі іï розвитку постає досягнення високого інтелектуального, морального та культурного потенціалу iii випускників, здатних до постійного професійного самовдосконалення, самостійного і постійного оволодіння новими знаннями, уміннями до типового та нестандартного їх використання.

Це вчитель, за визначенням О. Коберника, який: «має бути мобільним, готовим до стрімкових змін у змісті технологічної підготовки, здатним швидко переорієнтуватися» в нових ринкових умовах [3, с. 30].

Більш глибокий погляд на теоретичні досягнення та практичний стан досліджуваної проблеми розкриває і основні завдання реформування та оновлення змісту підготовки фахівця. За визначеням Н. Ничкало, існує пропорційна залежність «оновлення змісту навчання вищої освіти та підготовки кадрів» [6, с. 8].

Отже, практично всі дослідники сходяться на думці, що функції вчителя технологій не обмежуються тільки наданням професійних знань щодо формуванням в учнів трудових умінь і навичок, організацією навчально-виховного процесу. Він забезпечує розвиток особистості майбутнього трудівника, готує своїх вихованців до розв'язання конкретних виробничих, моральних, культурообумовлених задач у динамічних умовах сьогодення. Він сприяє подоланню соціально-економічної та духовної кризи в державі, формує готовність до самореалізації особистості.

\section{Література}

1. Вихрущ А. Система трудового виховання: закономірності становлення і розвитку / Анатолий Вихрущ // Трудова підготовка в закладах освіти. - 1998. - № 3. С. 28-34. 2. Заречная Л. П. Теория и практика профессионально-педагогической подготовки учителя обслуживающего труда: дисс. ... д-ра. пед. наук : 13.00 .08 «Теория и методика воспитания»/ Л. П. Заречная; Брянский госуд. пед. ин.-т. Брянск, 1999. - 543 с. 3. Коберник О. Модернізація підготовки майбутніх учителів / Олександр Коберник // Трудова підготовка в закладах освіти. - 2004. - № 4. - С. 28 30. 4. Криворізькому державному педагогічному університету - 70./ за заг. ред. професора В. К. Буряка. - Кривий Ріг, 2000. - 152 с. 5. Мазуренко С. Трудове виховання та політехнічна освіта в школах України (1917-1937)/ С. Мазуренко // Шлях освіти. - 2001. - № 3. - С. 45-49. 6. Ничкало Н. Г. Педагогіка вищої школи: крок у майбутнє / Неля Григорівна Ничкало // Сучасна вища школа: психолог. пед. аспект / за ред. Н. Г. Ничкало. - К. : ВІПОЛ, 1999. - 450 с. 7. ЦДІА, ф. 707, оп. 317, спр. 129, арк. 18, 26. 8. Kudawski L. Zarys metodyki zagecrekodzielniczych. - Poznan: Ksieg. Sw. Wojciecha, 1938. - 363 s. 9. Nowacki T. Tresci proces ksztalcenia politechnicznego.- 
Warszawa PZWS, 1966. - 203 s. 10. Plany studiow I programy nauczania przedmiotow kierunkowych// Kieruntk studiow Wychowanie Techniczne. Studia magisterskie. Uniwersytety I wyzszeszoly pedagogiczne, MNSzWiT, Warszawa, 1979. - S. 4-7.

УДК $378.011 .3: 373.3-051$

Вікторія Желанова

\section{ФЕНОМЕН «КОНТЕКСТ» У МІЖДИСЦИПЛІНАРНОМУ ВИМІРІ}

Желанова В. В. Феномен «контекст» у міждисциплінарному вимірі.

У представленій статті здійснено розгляд поняття «контекст» відповідно до феноменології лінгвістики (лінгвістичний контекст), психолінгвістики (екстралінгвальний контекст), філософії (індивідуальний смисловий контекст), психології (смислоутворювальний контекст), педагогіки (професійний контекст). Доведено, що поняття контекст у сучасному науковому просторі вийшло за межі свого традиційного лінгвістичного й психолінгвістичного розуміння та отримало загальнонаукове, зокрема, психолого-педагогічне, трактування. 3'ясовано, що міждисциплінарне розуміння категорії контекст синтезується саме в його педагогічному визначенні як смислоутворювальної категорії.

Ключові слова: міждисциплінарний аналіз, контекст, типи контексту, контекстне навчання.

Желанова В. В. Феномен «контекст» в междисциплинарном измерении.

В представленной статье рассмотрен феномен «контекст» в соответствии с феноменологией лингвистики (лингвистический контекст), психолингвистики (экстралингвистический контекст), философии (индивидуальный смысловой контекст), психологии (смыслообразующий контекст), педагогики (профессиональный контекст). Доказано, что понятие «контекст» в современном научном пространстве вышло за пределы своего традиционного лингвистического и психолингвистического понимания и получило общенаучное, в частности, психологопедагогическое, трактование. Выяснено, что междисциплинарное понимание категории контекст синтезируется именно в его педагогическом определении как смыслообразующей категории.

Ключевые слова: междисциплинарный анализ, контекст, типы контекста, контекстное обучение.

Zhelanova V. V. The phenomenon of «context» in an interdisciplinary dimension.

The article deals with the phenomenon of «context» in accordance with the phenomenology of linguistics (linguistic context), psycholinguistics (extralinguistic context), philosophy (individual semantic context), psychology (semantic context), education (professional context). It is proved that the concept of context in the modern scientific space has gone beyond its traditional linguistic and psycholinguistic understanding and received general scientific understanding and, in particular, psychological and pedagogical, interpretation. It was found out that an interdisciplinary understanding of the category context was synthesized in its definition as a pedagogical sense-category.

Key words: interdisciplinary analysis, context, context types, contextual learning.

Міждисциплінарна методологія $є$ грунтовною в дослідженні педагогічних феноменів. Оскільки саме вона відбиває тенденції сучасної педагогічної теорії та практики, що пов'язані 3 їх фундаменталізацією, поліпарадигмальністю та 